\title{
Benefits of prenatal and postnatal vitamin D supplementation
}

\author{
Alicja Kołodziejczyk-Nowotarska \\ Neonatal and Intensive Care Department, \\ Medical University of Warsaw, Poland \\ (iD) https://orcid.org/0000-0002-9380-4723 \\ Corresponding author: zuzialicja@gmail.com \\ Renata Bokiniec \\ Neonatal and Intensive Care Department, \\ Medical University of Warsaw, Poland \\ (iD) https://orcid.org/0000-0002-1164-8406 \\ Joanna Seliga-Siwecka \\ Neonatal and Intensive Care Department, \\ Medical University of Warsaw, Poland \\ (iD) https://orcid.org/0000-0002-4628-0541
}

DOI: https://doi.org/10.20883/medical.e498

Keywords: vitamin D deficiency, supplementation in pregnancy, infants, neonates

Published: 2021-03-30

How to Cite: Kołodziejczyk-Nowotarska A, Bokiniec R, Seliga-Siwecka J. Benefits of prenatal and postnatal vitamin D supplementation. JMS [Internet]. 2021 Mar 30;90(1):e498. doi:10.20883/medical.e498

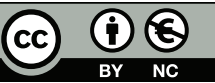

(C) 2021 by the author(s). This is an open access article distributed under the terms and conditions of the Creative Commons Attribution (CC BY-NC) licencse. Published by Poznan University of Medical Sciences

\begin{abstract}
The best evidence for the role of vitamin D in infants is its influence on skeletal growth, however, the pleiotropic actions of vitamin $D$ in the foetus and neonates are under-researched. The systematic reviews, based mostly on observational studies, suggest correlations between prenatal and postnatal supplementation and the occurrence of allergy, respiratory infections, sepsis or mental and behavioural development. Some of these studies focused on subgroups of neonates, such as preterm infants, investigating the influence inter alia on sepsis, bronchopulmonary dysplasia, and necrotising enterocolitis. Currently, there is a need for randomised trials for proof of the skeletal and pleiotropic effects of vitamin D in infants.
\end{abstract}

\section{Introduction}

The best evidence for the role of vitamin $D$ (vit D) is its influence on skeletal growth [1]. Dietary or supplemental intake of vitamin D after intestinal absorption or from 7-dehydrocholesterol in the skin is bonded to vit $D$ binding protein(DBP) in blood and converted to 25-hydroxyvitamin $D$ $(25(\mathrm{OH}) \mathrm{D})$ in the liver, which is hydroxylated to the active form 1,25 dihydroxycholecalciferol in the kidney. The active form increases intestinal calcium absorption, renal calcium and phosphate reabsorption, regulating mineral homeostasis and parathormone secretion. Conversely, parathormone, calcium and phosphorus regulate the level of the active form. Severe vit $D$ deficiency in children can lead to the development of nutritional rickets. In the first half of the 20th century, vit $D$ supplementation during infancy became common, accompanied by a huge decrease in the incidence of nutritional rickets [2]. Conversely, the available data does not provide definitive evidence that vit $D$ influences bone mineral density (BMD) in children [3]. Indeed, the data from 
the most recent Cochrane database systematic review does not provide sufficient evidence to assess the influence of vit $D$ deficiency in breastfed term infants on biochemical or radiological rickets and BMD. However, there is low-certainty evidence of maternal supplementation on the incidence of biochemical markers of rickets ( $14 \%$ decrease)in a subgroup of term infants with a high risk of vit D deficiency [4].

Preterm infants are particularly at risk of metabolic bone disease and vit D deficiency $[5,6]$. Additionally, vit $D$ deficiency at birth due to lack of supplementation during pregnancy is a risk factor for reduced intrauterine bone growth due to inferior placentation [7]. The most recent metaanalysis of observational studies considered the influence of vit D deficiency (below $20 \mathrm{ng} / \mathrm{ml}$ ) during pregnancy on the occurrence of small for gestational age infants and preterm birth [8]. The benefits of maintaining higher vit $D$ levels in pregnant women to decrease preterm birth and small for gestational age infants were observed inter alia in studies with a large sample size conducted in California and Sweden $[9,10]$. However, other meta-analyses which also included randomised trials suggest that a deficiency rather than insufficiency is associated with preterm birth [11]. Low birth weight is associated with increased illness and mortality in infancy, consequently, reduced height in later life [12]. A lower areal BMD in early adulthood is more frequently observed in studies of preterm and very low birth weight infants $[13,14]$ but it is not clear whether this can lead to osteoporosis in adulthood. Systematic reviews which evaluate the impact of vit D supplementation in pregnancy on infant BMD remain inconclusive [15], only confirming the prevention of neonatal hypocalcaemia in infants born to mothers who received vit D supplements [16]. A double-blind randomised trial with a good rate of follow-up conducted in Denmark demonstrated an association between high vit D supplementation during pregnancy ( $2400 \mathrm{IU}$ ) and $50 \%$ reduced odds of enamel defects in children at six years old [17].

Currently, the most prevalent role of non-skeletal vit $D$ under investigation is its immunomodulatory impact. The vit $D$ receptor is present on $B$ cells, $T$ cells, macrophages, and dendritic cells and can play a role in the immune response [18]. An inappropriate immune response influences the development of autoimmune disease. A system- atic review based on observational studies suggests a correlation between early vit $D$ supplementation in children and protection against the occurrence of type 1 diabetes, with dose response effects [19]. In a large sample size birth-cohort study conducted in Finland, children with high dose vit D supplementation (2000 IU) had a significantly reduced risk of type 1 diabetes [20]. The meta-analysis investigating inter alia the influence of prenatal and postnatal early vit $D$ supplementation on allergic rhinitis, wheezing and asthma in children concluded that due to limited information, an early prevention impact still remains uncertain [21]. Nevertheless, a combined analysis of two large, randomised trials of vit D supplementation in pregnancy performed in the United States shows a significant $26 \%$ decrease in wheezing or asthma in the offspring by 3 years of age and was more pronounced for children whose mothers had achieved a sufficient 25(OH)D level [22]. However, in a Danish study, the protective effect of high vit $D$ supplementation during pregnancy on persistent wheezing and the occurrence of asthma in the offspring at the age of 3 years was not observed at 6 years of age (limitation: target sample size was not achieved on follow-up). The Finish researchers performed the study based on the hypothesis of a positive correlation between vit $D$ supplementation in infancy and an increased risk of atopy and allergic rhinitis in adult life [23]. Also, the potential vit $D$ impact on food allergy among infants through promotion of immunological tolerance is under investigation. Since data from different observational studies are contradictory [24], there is a need to undertake a randomised trial targeted at this potential correlation.

Secondly, the vit D dependent immune response modulates the development of infectious disease. Vit D receptors can be found not only within the immune system but also on airway epithelial cells. Respiratory tract infections among neonates are mostly viral in origin, typically manifesting as wheezing, pneumonia or bronchiolitis. The influence of vit $D$ supplementation in pregnancy and the neonatal period on the development and severity of the upper or lower respiratory tract infections in early childhood is currently under investigation in clinical trials. However, most studies concur that vit D status in young children modulates the occurrence and severity of respiratory infections $[25,26]$. In a 
recent metanalysis, investigators examined the hypothesis that vit $D$ can modulate the immune response in neonatal sepsis (NS) [27], an infection in the first 28 days of life including bloodstream infections, meningitis, and pneumonia. However, the analysis was based solely on observational studies and there was significant heterogeneity among the studies. Furthermore, an analysis was performed in a subgroup for an association between cord blood and maternal vit D level and the development of early-onset sepsis in term infants, showing a positive correlation between vit $D$ deficiency during pregnancy and at birth and incidence of NS including early onset.

The influence of vit $D$ on the immune response in preterm infants is a separate discussion. The most recent studies consider an association between maternal, cord or neonatal blood vit $D$ level in a group of premature neonates and the occurrence of NS as well as necrotising enterocolitis (NEC), which in origin favour a pro-inflammatory mechanism $[28,29]$. In Cetinkaya's study, the maternal vit $D$ level was a significant predictor of NEC, whereas in Say's study, the cord blood vit $D$ level did not correlate with the risk of NS. Furthermore, antenatal vit D deficiency is linked to both airway inflammation and impaired anatomical and functional lung development which can lead to bronchopulmonary dysplasia in preterm infants. A meta-analysis based on four trials detected a significant association between vit $D$ deficiency at birth and the development of bronchopulmonary dysplasia based on oxygen dependency at 28 days of age or 36 weeks of corrected age with no significant heterogeneity existing between the studies [30].

The last potential effect of vit D described in this short review is the effect on brain development, including neurotrophic and neuroprotective actions and changes in brain structure. A prospective study conducted on mother-child pairs reported a correlation between insufficient vit $D$ pregnancy level and offspring language impairment at 5 and 10 years of age without offspring behavioural and emotional difficulties at any age [31]. Another large-scale prospective cohort study showed that higher $25(\mathrm{OH}) \mathrm{D}$ concentrations in pregnancy are associated with improved offspring mental and psychomotor scores in infancy [32]. The limitations of the study included the residual possibility of confounding by parental intelli- gence and lack of information on neonatal vit D supplementation. However, these results suggest that an optimal 25(OH)D level could improve early foetal brain development. Contrary to the latter research, a prospective cohort study with long term follow-up did not provide evidence inter alia that a higher maternal vit D status can support scholastic achievement among offspring [33].

\section{Conclusions}

The influence of vit $D$ on neonatal health is one of the hot topics of the previous decade. The investigation of the skeletal and pleiotropic roles of vit $D$ among infants is based on an increasing number of observational studies and their systematic reviews but there is a great need for randomised trials.

\section{Abbreviations}

Vit D - vitamin D; BMD - bone mineral density; NS - neonatal sepsis; 25(OH)D - 25-hydroxyvitamin D; NEC - necrotising enterocolitis

\section{Acknowledgements}

\section{Conflict of interest statement}

The authors declare no conflict of interest.

\section{Funding sources}

There are no sources of funding to declare.

\section{References}

1. Montecimo M. Biological and Molecular Effects of Vitamin D on Bone. In: Holick M, ed. Nutrition and Health. Vitamin D: Physiology, Molecular Biology, and Clinical Applications. 2nd edition. New York: Springer Science \& Business Media; 2010:189-211, 651-669.

2. Braegger $C$, Campoy C, Colomb V, Decsi T, Domellof $M$, Fewtrell M, Hojsak I, Mihatsch W, Molgaard C, Shamir $R$, Turck D, van Goudoever J. Vitamin D in the Healthy European Paediatric Population. Journal of Pediatric Gastroenterology \& Nutrition. 2013 Jun;56(6):692701. https://doi.org/10.1097/mpg.0b013e31828f3c05

3. Winzenberg T, Powell S, Shaw KA, Jones G. Effects of vitamin $D$ supplementation on bone density in healthy children: systematic review and meta-analysis. BMJ. 2011 Jan 25;342(jan25 1):c7254-c7254. https://doi.org/10.1136/bmj.c7254

4. Tan ML, Abrams SA, Osborn DA. Vitamin D supplementation for term breastfed infants to prevent vitamin $D$ deficiency and improve bone health. . Cochrane Database of Systematic Reviews. 2020 Dec 11; https://doi.org/10.1002/14651858.cd013046.pub2 
5. Czech-Kowalska J. Osteopenia wcześniaków algorytm postępowania. Klinika Pediatryczna. 2019;21:11-7.

6. Czech-Kowalska J. Vitamin D in preterm infants. In: Watson R, Mahadevan D, eds. Handbook of nutrition and diet in therapy of bone diseases. The Netherlands: Wageningen Academic Publishers; 2016:233-46.

7. Maugeri A, Barchitta M, Blanco I, Agodi A. Effects of Vitamin D Supplementation During Pregnancy on Birth Size: A Systematic Review and Meta-Analysis of Randomized Controlled Trials. Nutrients. 2019 Feb 20;11(2):442. https://doi.org/10.3390/nu11020442

8. Tous $M$, Villalobos $M$, Iglesias L, Fernández-Barrés $S$, Arija V. Vitamin D status during pregnancy and offspring outcomes: a systematic review and metaanalysis of observational studies. European Journal of Clinical Nutrition. 2019 Jan 25;74(1):36-53. https:// doi.org/10.1038/s41430-018-0373-x

9. McDonnell SL, Baggerly KA, Baggerly CA, Aliano JL, French CB, Baggerly LL, Ebeling MD, Rittenberg CS, Goodier CG, Mateus Niño JF, Wineland RJ, Newman RB, Hollis BW, Wagner CL. Maternal 25(OH)D concentrations $\geq 40 \mathrm{ng} / \mathrm{mL}$ associated with $60 \%$ lower preterm birth risk among general obstetrical patients at an urban medical center. Rosenfeld CS. PLOS ONE. 2017 Jul 24;12(7):e0180483. https://doi.org/10.1371/ journal.pone.0180483

10. Bärebring L, Bullarbo $M$, Glantz $A$, Hulthén L, Ellis J, Jagner $\AA$, Schoenmakers I, Winkvist A, Augustin $\mathrm{H}$. Trajectory of vitamin $D$ status during pregnancy in relation to neonatal birth size and fetal survival: a prospective cohort study. BMC Pregnancy and Childbirth. 2018 Feb 13;18(1). https://doi.org/10.1186/ s12884-018-1683-7

11. Zhou S, Tao Y, Huang K, Zhu B, Tao F. Vitamin D and risk of preterm birth: Up-to-date meta-analysis of randomized controlled trials and observational studies. Journal of Obstetrics and Gynaecology Research. 2017 Feb;43(2):247-256. https://doi. org/10.1111/jog.13239

12. Fewtrell MS, Cole TJ, Bishop NJ, Lucas A. Neonatal factors predicting childhood height in preterm infants: Evidence for a persisting effect of early metabolic bone disease?. The Journal of Pediatrics. 2000 Nov;137(5):668-673. https://doi.org/10.1067/ mpd.2000.108953

13. Balasuriya CND, Evensen KAI, Mosti MP, Brubakk A, Jacobsen GW, Indredavik MS, Schei B, Stunes AK, Syversen U. Peak Bone Mass and Bone Microarchitecture in Adults Born With Low Birth Weight Preterm or at Term: A Cohort Study. The Journal of Clinical Endocrinology \& Metabolism. 2017 Apr 27;102(7):24912500. https://doi.org/10.1210/jc.2016-3827

14. Xie LF, Alos N, Cloutier A, Béland C, Dubois J, Nuyt AM, Luu TM. The long-term impact of very preterm birth on adult bone mineral density. Bone Reports. 2019 Jun;10:100189. https://doi.org/10.1016/j. bonr.2018.100189

15. Curtis EM, Moon RJ, Harvey NC, Cooper C. Maternal vitamin D supplementation during pregnancy. British Medical Bulletin. 2018 Apr 19;126(1):57-77. https:// doi.org/10.1093/bmb/ldy010
16. Berdal A, Papagerakis P, Hotton D, Bailleul-Forestier I, Davideau J. Ameloblasts and odontoblasts, target-cells for 1,25-dihydroxyvitamin D3: a review. Int J Dev Biol. 1995;31(1):257-62. PMID 7626415

17. Nørrisgaard PE, Haubek D, Kühnisch J, Chawes BL, Stokholm J, Bønnelykke K, Bisgaard H. Association of High-Dose Vitamin D Supplementation During Pregnancy With the Risk of Enamel Defects in Offspring. JAMA Pediatrics. 2019 Oct 1;173(10):924. https://doi. org/10.1001/jamapediatrics.2019.2545

18. Schwalfenberg GK. A review of the critical role of vitamin $D$ in the functioning of the immune system and the clinical implications of vitamin D deficiency. Molecular Nutrition \& Food Research. 2010 Sep 7;55(1):96-108. https://doi.org/10.1002/ mnfr.201000174

19. Zipitis C, Akobeng A. Vitamin D supplementation in early childhood and risk of type 1 diabetes: a systematic review and meta-analysis. Archives of Disease in Childhood. 2008 Jun 1;93(6):512-517. https:// doi.org/10.1136/adc.2007.128579

20. Hyppönen $E$, Läärä $E$, Reunanen $A$, Järvelin $M$, Virtanen SM. Intake of vitamin D and risk of type 1 diabetes: a birth-cohort study. The Lancet. 2001 Nov;358(9292):1500-1503. https://doi.org/10.1016/ s0140-6736(01)06580-1

21. Yepes-Nuñez JJ, Brożek JL, Fiocchi A, Pawankar R, Cuello-García C, Zhang Y, Morgano GP, Agarwal A, Gandhi S, Terracciano L, Schünemann HJ. Vitamin D supplementation in primary allergy prevention: Systematic review of randomized and non-randomized studies. Allergy. 2017 Aug 11;73(1):37-49. https://doi. org/10.1111/all.13241

22. Wolsk HM, Chawes BL, Litonjua AA, Hollis BW, Waage J, Stokholm J, Bønnelykke K, Bisgaard H, Weiss ST. Prenatal vitamin D supplementation reduces risk of asthma/recurrent wheeze in early childhood: A combined analysis of two randomized controlled trials. Cameron DW. PLOS ONE. 2017 Oct 27;12(10):e0186657. https://doi.org/10.1371/journal. pone. 0186657

23. Hyppönen E, Sovio U, Wjst M, Patel S, Pekkanen J, Hartikainen A, Järvelinb M. Infant Vitamin D Supplementation and Allergic Conditions in Adulthood: Northern Finland Birth Cohort 1966. Annals of the New York Academy of Sciences. 2004 Dec;1037(1):8495. https://doi.org/10.1196/annals.1337.013

24. Giannetti A, Bernardini L, Cangemi J, Gallucci M, Masetti R, Ricci G. Role of Vitamin D in Prevention of Food Allergy in Infants. Frontiers in Pediatrics. 2020 Aug 18;8. https://doi.org/10.3389/fped.2020.00447

25. Zisi D, Challa A, Makis A. The association between vitamin $D$ status and infectious diseases of the respiratory system in infancy and childhood. Hormones. 2019 Nov 25;18(4):353-363. https://doi.org/10.1007/ s42000-019-00155-z

26. Christensen N, Søndergaard J, Fisker N, Christesen HT. Infant Respiratory Tract Infections or Wheeze and Maternal Vitamin D in Pregnancy. Pediatric Infectious Disease Journal. 2017 Apr;36(4):384-391. https://doi.org/10.1097/inf.0000000000001452 
27. Workneh Bitew Z, Worku T, Alemu A. Effects of vitamin D on neonatal sepsis: A systematic review and meta-analysis. Food Science \& Nutrition. 2020 Nov 10;9(1):375-388. https://doi.org/10.1002/fsn3.2003

28. Cetinkaya M, Erener-Ercan T, Kalayci-Oral T, Babayiğit A, Cebeci B, Semerci SY, Buyukkale G. Maternal/ neonatal vitamin $D$ deficiency: a new risk factor for necrotizing enterocolitis in preterm infants? Journal of Perinatology. 2017 Mar 23;37(6):673-678. https:// doi.org/10.1038/jp.2017.18

29. Say B, Uras N, Sahin S, Degirmencioglu H, Oguz SS, Canpolat FE. Effects of cord blood vitamin D levels on the risk of neonatal sepsis in premature infants. Korean Journal of Pediatrics. 2017;60(8):248. https:// doi.org/10.3345/kjp.2017.60.8.248

30. Park HW, Lim G, Park Y, Chang M, Son JS, Lee R. Association between vitamin $\mathrm{D}$ level and bronchopulmonary dysplasia: A systematic review and meta-analysis. Ehrhardt H. PLOS ONE. 2020 Jul 6;15(7):e0235332. https://doi.org/10.1371/journal. pone. 0235332

31. Whitehouse AJO, Holt BJ, Serralha M, Holt PG, Kusel $\mathrm{MMH}$, Hart PH. Maternal Serum Vitamin D Levels During Pregnancy and Offspring Neurocognitive Development. PEDIATRICS. 2012 Feb 13;129(3):485493. https://doi.org/10.1542/peds.2011-2644

32. Morales E, Guxens M, Llop S, Rodriguez-Bernal CL, Tardon A, Riano I, Ibarluzea J, Lertxundi N, Espada M, Rodriguez A, Sunyer J. Circulating 25-Hydroxyvitamin D3 in Pregnancy and Infant Neuropsychological Development. PEDIATRICS. 2012 Sep 17;130(4):e913e920. https://doi.org/10.1542/peds.2011-3289

33. Strøm M, Halldorsson TI, Hansen S, Granström C, Maslova E, Petersen SB, Cohen AS, Olsen SF. Vitamin $D$ Measured in Maternal Serum and Offspring Neurodevelopmental Outcomes: A Prospective Study with Long-Term Follow-Up. Annals of Nutrition and Metabolism. 2014;64(3-4):254-261. https://doi. org/10.1159/000365030 